SheININ, R. (1959). J. gen. Microbiol. 21, 124-134

\title{
The Localization of the Cell-Bound Penicillinase of Bacillus cereus in Protoplasts
}

\author{
By ROSE SHEININ* \\ National Institute for Medical Research, Mill Hill, London, N.W. 7
}

SUMMARY : Protoplasts of Bacillus cereus 569 and B. cereus 569/H were shown to be as competent as intact cells in the induced and constitutive formation of penicillinase, as well as in other biochemical activities. It was demonstrated that the cellbound penicillinase was localized at or near the cell surface. The $\beta$-penicillinase fraction was released by digestion of the cell wall and by washing of the protoplast membrane. However, the $\gamma$-penicillinase was tightly bound to the cytoplasmic membrane. It was obtained in a soluble form by treating the membrane with sonic vibration or with fat solvents.

It was demonstrated by Pollock (1956) that of the total penicillinase formed constitutively by Bacillus cereus $569 / \mathrm{H}$, and as a result of induction by $B$. cereus 569 , about $85 \%$ was exocellular ( $\alpha$-penicillinase). $\beta$-penicillinase, the fraction of cell-bound enzyme which could be neutralized by anti-exopenicillinase serum, could be partially removed from the cell by washing; but the $\gamma$-penicillinase, which is an immunologically and physicochemically distinct fraction, was very tightly associated with the cell. Attempts to obtain the $\gamma$-penicillinase in a soluble form were only partially successful. The observation that such soluble enzyme was obtained only after disruption of the intact organisms suggested that some of the $\gamma$-penicillinase might exist as a soluble cytoplasmic constituent. However, the results did not permit the exclusion of the possibility that all the enzyme was bound at the surface of the cell and was released when the surface structure was disintegrated.

In the course of an investigation of the formation of penicillinase in protoplasts of Bacillus cereus it was demonstrated that all cell-bound enzyme was located at the cell surface. A portion, $\beta$-penicillinase, was associated with the cell wall and could be removed by dissolution of the wall; the $\gamma$-penicillinase was exclusively localized in or at the cell membrane. Little or no penicillinase could be detected in the cell cytoplasm.

\section{METHODS}

Organisms. Bacillus cereus, NRRL 569, which can be induced to form penicillinase (Pollock, 1950). B. cereus 569/H, a mutant strain derived from NRRL 569, which produces this enzyme constitutively (Kogut, Pollock \& Tridgell, 1956).

Media and conditions of growth. Organisms were grown in the casein hydrolysate medium described by Pollock (1957). In some instances sodium citrate

* Present address: c/o Ontario Cancer Institute, 500 Sherbourne Street, Toronto 5, Ontario, Canada. 
was omitted without effect on the growth of the organism or on the other properties under investigation. Medium was automatically inoculated with a suspension of spores (Pollock, 1953) which had been allowed to germinate in stationary culture at $35^{\circ}$ for $10-12 \mathrm{hr}$. The inoculated culture was then shaken at $35^{\circ}$.

The automatic inoculation was achieved using the apparatus designed by Dr H. J. Rogers and Dr D. A. Lowther. The spore suspension was placed in a $25 \mathrm{ml}$. separatory funnel which was connected to a receiving flask by rubber tubing. The rubber tubing was held closed by two metal strips which were firmly screwed together. One of these strips was connected by an armature to a solenoid, which in turn was connected to an automatic interval timer. To permit free flow through the rubber tubing the metal strip was pulled back by the magnetic force of the solenoid, which was energized by the preset timer.

Preparation of protoplasts from Bacillus cereus. Protoplasts of $B$. cereus 569 and $B$. cereus $569 / \mathrm{H}$ were prepared by a method based on that described by Dark \& Strange (1957). Modifications were necessitated by the fact that these organisms were prone to lysis when subjected to repeated washing in dilute buffer solutions, and the protoplasts were unstable in the absence of magnesium ion. The final procedure adopted was as follows.

Organisms grown to the exponential phase (stationary phase organisms were relatively insensitive to protoplast formation by the method used) were harvested by centrifugation; washed once with a solution of McIlvaine's buffer ( $\mathrm{pH} 7 \cdot 0 ; \mathrm{Na}_{2} \mathrm{HPO}_{4}, 0.017 \mathrm{M}$ and citric acid, $0.018 \mathrm{M}$, Clark, 1928) containing glucose $(1 \%, \mathrm{w} / \mathrm{v})+\mathrm{MgSO}_{4}, 0.05 \mathrm{M}$ and resuspended in a solution of the following: sucrose, $0.3 \mathrm{M}$; $\mathrm{CoSO}_{4}, 8.5 \times 10^{-4} \mathrm{M} ; \mathrm{MgSO}_{4}, 0.05 \mathrm{M}$; sodium citrate, $5 \times 10^{-3} \mathrm{M}$; potassium phosphate buffer $(\mathrm{pH} 7 \cdot 0), 0.01 \mathrm{M}$; glucose, $1 \%(\mathrm{w} / \mathrm{v}) ; 2 \mathrm{ml}$. of a solution of lytic enzyme (see below) in $5 \mathrm{ml}$. of reaction mixture. The organisms were incubated without shaking at $37^{\circ}$.

When the formation of protoplasts was complete, as judged by their appearance by phase-contrast microscopy, they were collected by centrifugation and resuspended as indicated in the text. To assess the degree of protoplast formation a portion of the suspension was diluted ten times with water, thereby lysing the protoplasts and leaving intact the unaltered organisms. The optical density of this diluted suspension was compared with that of a similar suspension of a control culture of organisms incubated in the absence of lytic enzyme. The difference between the optical densities of these two suspensions was taken as a measure of the proportion of the organisms converted to protoplasts.

These microscopic and optical density methods for measuring protoplast formation would not necessarily indicate the presence of very small numbers of residual cells. In order to be certain that the biochemical activities of a protoplast preparation was not due to such intact cells, a cell control was included in all experiments designed to study the synthetic and metabolic properties of protoplasts and protoplast substructures, i.e. the activity of a protoplast suspension was compared with that of a protoplast suspension lysed with water, and therefore containing only intact cells. Complete 
$(99-100 \%)$ conversion of cells to protoplasts was concluded to have occurred if $(a)$ no intact cells could be detected with phase-contrast microscopy, $(b)$ the optical density of a lysed protoplast preparation approached zero, $(c)$ the penicillinase-forming ability of a water-lysed preparation was zero.

Preparation of lytic enzymes for protoplast formation. Two lytic enzymes, which attack the cell wall of Bacillus cereus 569 and $B$. cereus $569 / \mathrm{H}$, were isolated from the former organism, essentially by the procedure described by Strange \& Dark $(1957 b)$. Complete sporulation and the onset of spore release (judged by phase-contrast microscopy) was attained within 19-24 hr. when cultures of $B$. cereus 569 in ' $S$ '-broth (Pollock, 1953) were shaken at $35^{\circ}$ in a conical flask, the volume of which was ten times that of the culture volume. The cultures were shaken on a reciprocating shaker described by Kantorowicz (1951), at a speed of 85 strokes/min. on a rack moving with an amplitude of 3 in./stroke. Under these conditions optimum aeration was ensured. Washed organisms were incubated without shaking at $\mathrm{pH} 5 \cdot 6$ with toluene at $37^{\circ}$ for $2 \mathrm{hr}$. The filtered supernatant fluid was active in forming protoplasts. However, the dissolved toluene produced lysis of the protoplasts; thus partial isolation of the enzymes was necessary. The spore coat enzyme (S enzyme) was isolated by precipitation at $\mathrm{pH} 3$ using McIlvaine's buffer (composed of $\mathrm{Na}_{2} \mathrm{HPO}_{4}, 0.004 \mathrm{M}+$ citric acid, $0.08 \mathrm{M}$; Clark, 1928). The precipitate was dissolved in a solution of sodium bicarbonate $(0.01 \mathrm{M})+$ sodium citrate $(0.05 \mathrm{M})$. The enzyme was reprecipitated at $\mathrm{pH} 3$, redissolved in a minimum volume of the bicarbonate + citrate solution and stored at $-20^{\circ}$. The vegetative cell enzyme ( $V$ enzyme) was obtained from the supernatant fluid of the first $\mathrm{pH} 3$ precipitation by saturating it with solid ammonium sulphate and leaving for several hr. at $2^{\circ}$. The precipitate formed was collected by filtration. It was dissolved in bicarbonate + citrate solution and was dialysed overnight at $2^{\circ}$ against distilled water. The dialysed solution was stored at $-\mathbf{2 0}^{\circ}$. When stored in this way the $\mathbf{S}$ and $\mathbf{V}$ enzymes were stable for at least 5 months.

Penicillinase assay. Total penicillinase activity was measured by the method of Henry \& Housewright (1947) in the presence of $0 \cdot 3 \%$ gelatin. It was established that the various components of the media and buffer mixtures used had no effect on the assay. To measure the amount of extracellular $\alpha$-penicillinase and cell-bound $\beta$-penicillinase present in any sample, $1 \mathrm{ml}$. portions were pre-incubated at room temperature in Warburg flasks with $0.5 \mathrm{ml}$. of a solution of anti- $\alpha$-penicillinase serum (Pollock, 1956). The antibody was added in a concentration three times that required for maximal neutralization of enzyme present. The final volume of assay mixture was adjusted to $3 \cdot 0 \mathrm{ml}$.

$\gamma$-Penicillinase. The non-neutralizable enzyme activity was taken as a measure of the amount of $\gamma$-penicillinase present, after allowing for the residual activity of the enzyme-antibody complex. It was established that the penicillinase activity not neutralized by anti-exoenzyme serum was rapidly inactivated by iodine (Pollock, 1956), by using the iodometric assay system described by Citri (1958). 


\title{
RESULTS
}

\author{
Protoplasts of Bacillus cereus
}

When the $S$ enzyme or the $V$ enzyme (isolated from Bacillus cereus 569), both of which attack cell wall material, was allowed to act in a medium of high osmotic pressure on either $B$. cereus 569 or $B$. cereus $569 / \mathrm{H}$, the structural integrity of the organisms disappeared. It was seen by phase-contrast microscopy that the bacillary form of the organism was lost and was replaced by a spherical form which was highly sensitive to osmotic shock.

Of the several chemical tests for protoplasts put forward by Brenner et al. (1958) none has yet been applied. However, electron microscopy of the spherical forms obtained (PI. 1, fig. 1) indicated that these structures are devoid of adhering fragments of cell wall. Remnants of cell wall when present were clearly seen as, for example, in the case of the spore seen in Pl. 1, fig. 2, still encased by cell wall. The electron micrographs of the spherical forms obtained from Bacillus cereus 569 and B. cereus $569 / \mathrm{H}$ are similar to those of the denuded protoplasts derived from Bacillus megaterium by the action of lysozyme (McQuillen, 1959). They are quite unlike the micrographs of the spherical forms obtained when Escherichia coli is grown in the presence of penicillin, which were shown by McQuillen (1958) to be enveloped in fragments of cell wall. These microscopical observations, together with the finding of Strange \& Dark $(1957 a, b)$ that the lytic enzymes derived from sporulated Bacillus cereus produce almost complete digestion of vegetative cell walls, make it likely that naked protoplasts are indeed obtained by the procedure used in the present investigation.

\section{Biochemical capabilities of protoplasts of Bacillus cereus}

Studies of the biochemical activities of protoplasts of Bacillus cereus 569 and $B$. cereus $569 / \mathrm{H}$ confirmed findings obtained with protoplasts of other micro-organisms (McQuillen, 1958). These subcellular structures oxidize endogenous substrates and added glucose and glutamate at approximately the same rate as do intact organisms, incorporate amino acids into their proteins and utilize glycine for the formation of nucleic acid purines. When the protoplasts of $B$. cereus were incubated in a growth medium supplemented with sucrose $(0.3 \mathrm{M})$ and magnesium ions $(0.05 \mathrm{M})$, their volume increased several fold, but no division of protoplasts or reversion to the bacillary form was observed during $3 \frac{1}{2} \mathrm{hr}$. Constitutive penicillinase formation was demonstrated in protoplasts of $B$. cereus $569 / \mathrm{H}$. The observation of Kramer \& Straub (1955) that preinduced $B$. cereus 569 when converted to the spherical forms (by the use of lysozyme) formed enzyme, was confirmed. It was also found that protoplasts could be directly induced to form penicillinase. In the case of both constitutive and induced enzyme synthesis, the rate and extent of enzyme formation by protoplasts was of the same order as that exhibited by intact organisms. The release of exocellular $\alpha$-penicillinase to the medium was unimpaired by removal of the cell wall; for of the total penicillinase synthesized 
by protoplasts of $B$. cereus 569 and $569 / \mathrm{H}$, and by intact organisms, the same proportion was formed as exo-enzyme in each case.

\section{The localization of penicillinase in protoplasts}

Weibull (1956) showed that lysis of protoplasts in a hypotonic medium containing magnesium ions, gave rise to intact cell membranes. This finding made possible a limited step-wise dissection of the bacterium. This technique has been applied in a study of the distribution of penicillinase among the cell fractions of Bacillus cereus.

The procedure employed and the fractions obtained are described in Fig. 1. Protoplasts of Bacillus cereus 569 and $B$. cereus $569 / \mathrm{H}$, when resuspended in distilled water, were completely disrupted. Electron microscopy revealed that the resulting suspension contained large particles which could be sedimented at $15,000 \mathrm{~g}$, smaller particles which sedimented at $30,000 \mathrm{~g}$ and particles which were brought down at $105,000 \mathrm{~g}$. The final supernatant fluid was particle-free.

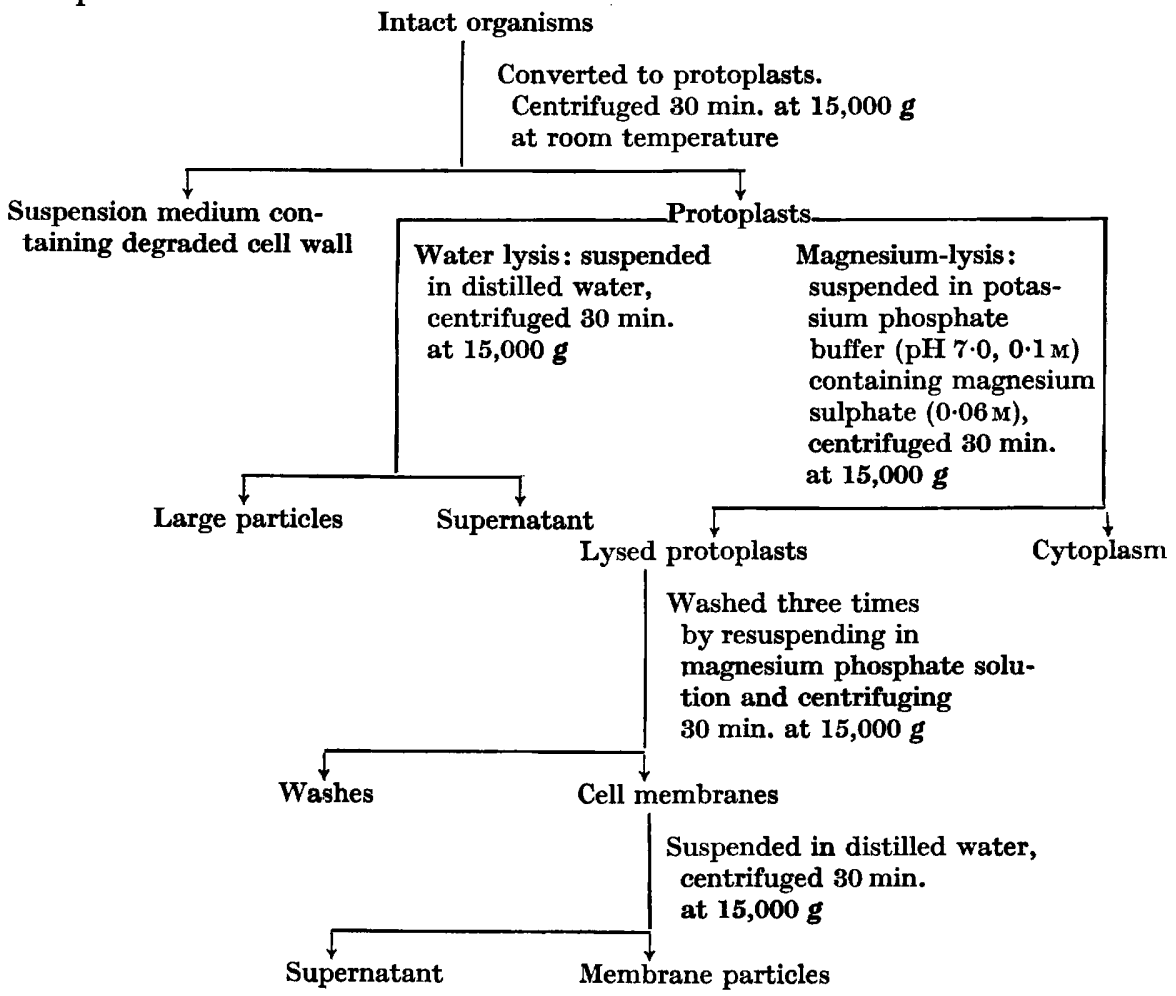

Fig. 1. Procedure for the isolation of cell fractions from Bacillus cereus. All manipulations for the fractionation of protoplasts were carried out at $2^{\circ}$.

However, when the protoplasts were suspended in a solution of magnesium ions $\left(\mathrm{MgSO}_{4}, 0.05 \mathrm{M}\right.$ in potassium phosphate buffer $\left.\mathrm{pH} 7.0,0.01 \mathrm{M}\right)$, there occurred lysis of a type such that much of the intracellular protein and RNA was 
released into the medium, although the cytoplasmic membrane retained its structural integrity. These membranes were harvested by centrifugation at $15,000 \mathrm{~g}$. A preparation of thrice-washed membranes is seen in Pl. 1, fig. 3. When suspended in water the membrane structure disintegrated, giving rise to a considerable quantity of particles which sedimented at $15,000 \mathrm{~g}$ and $30,000 \mathrm{~g}$, but little or no material which sedimented at $105,000 \mathrm{~g}$.

In Fig. 2 are presented the results of a study of the distribution of penicillinase activity in cell fractions of Bacillus cereus $569 / \mathrm{H}$. Similar results were obtained using induced $B$. cereus 569. It is clear that of the penicillinase associated with once-washed organisms (i.e. the cell-bound enzyme described by Pollock, 1956), half was released as a result of the digestion of the cell wall and half remained bound to the resulting protoplasts. Over $90 \%$ of the protoplast-bound enzyme was recovered in the cell membranes, and of this almost all was found in the large particles which were formed when the membranes were disintegrated. Taking into account the fragility of the membrane and the inaccuracies inherent in the methods of separation of the cell fractions, it seems most probable that the protoplast-bound penicillinase of $B$. cereus 569 and $569 / \mathrm{H}$ is localized in or on the cell membrane. Little can be detected in the cytoplasm.

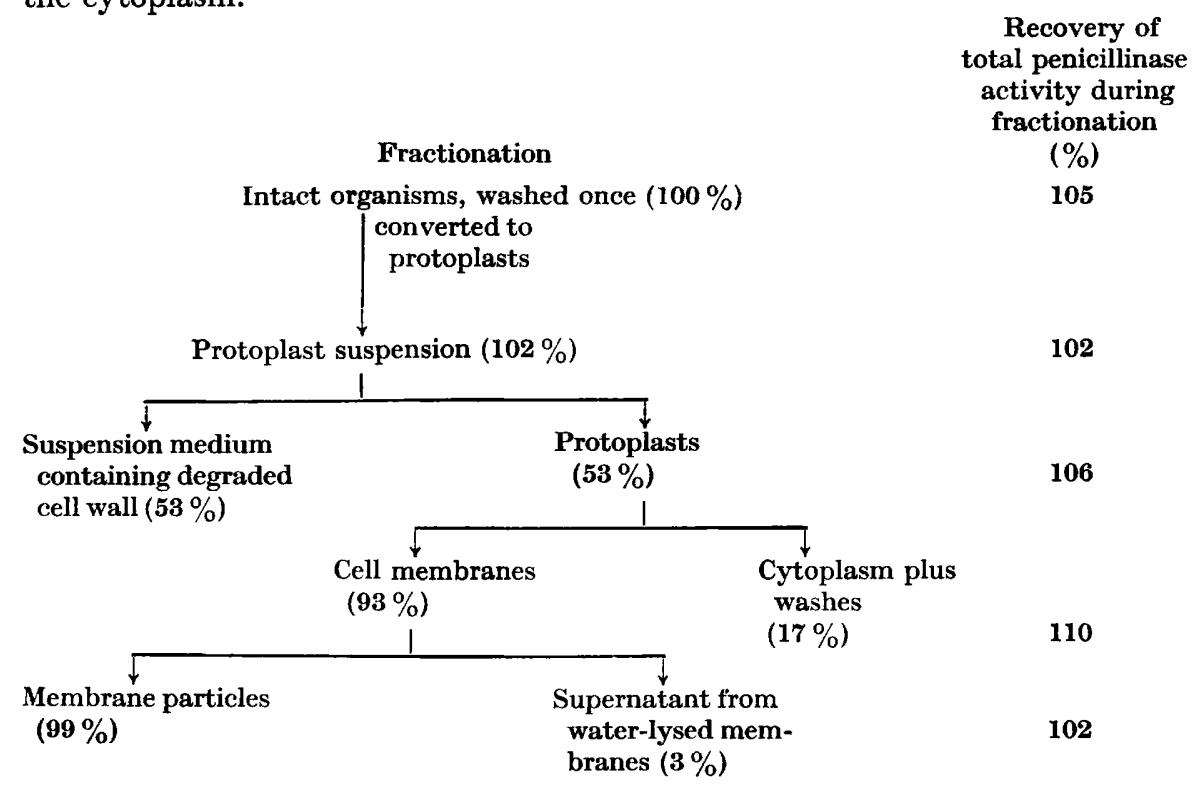

Fig. 2. Distribution of penicillinase activity in fractions of Bacillus cereus $569 / \mathrm{H}$. Fractions were obtained as described in Fig. 1. The figures in parentheses indicate that percentage of the penicillinase activity of the previous fraction recovered in the fraction noted before the bracket.

Nature of the penicillinase in cell fractions of Bacillus cereus

Pollock (1956) showed that the penicillinase activity of intact Bacillus cereus is due to the presence of two distinct protein entities: $(a) \beta$-penicillinase which is detected by its inactivation by antiserum to the $\alpha$-penicillinase, and by its 
relative iodine insensitivity; (b) $\gamma$-penicillinase which is unaffected by this antiserum, but is inactivated by iodine. A study of the sensitivity of the penicillinase in cell fractions of $B$. cereus $569 / \mathbf{H}$ to anti- $\alpha$-serum (Table 1 ) revealed that whereas the penicillinase activity of intact organisms, protoplasts and unwashed membranes was partially neutralized (c.15\%) by the antiserum, that of the washed membranes and particles derived from them was totally unaffected by the serum. It was further demonstrated (Table 1) that the nonneutralizable penicillinase of the membrane preparations was very rapidly inactivated by iodine, since in the iodometric assay test (Citri, 1958) no decolorization of iodine by these preparations was observed even after $24 \mathrm{hr}$. Under the conditions of the assay, an amount of $\alpha$ - or $\beta$-penicillinase of equivalent activity decolorized the iodine within 5-10 min. It would seem, therefore, that the penicillinase of the membranes is $\gamma$-penicillinase, and that in the intact organisms and protoplasts a small amount of $\beta$-penicillinase is adsorbed in a form which can readily be removed by washing.

Table 1. Sensitivity of the penicillinase activity of cell fractions of Bacillus cereus 569/H to anti-exopenicillinase serum and to iodine

\begin{tabular}{|c|c|c|c|c|}
\hline $\begin{array}{l}\text { Expt. } \\
\text { no. }\end{array}$ & Fraction & $\begin{array}{c}\text { Percentage } \\
\text { neutralization } \\
\text { by } \\
\text { anti- } \alpha \text {-serum } \\
\text { (experimental } \\
\text { observation) }\end{array}$ & $\begin{array}{c}\text { Percentage } \\
\text { unneutralizable } \\
\text { penicillinase } \\
\text { activity* }\end{array}$ & $\begin{array}{l}\text { Decolorization } \\
\text { of iodine }\end{array}$ \\
\hline 1 & $\begin{array}{l}\text { Intact organisms, washed } \\
\text { once }\end{array}$ & 16 & 78 & $\begin{array}{l}\text { Complete within } \\
\text { few minutes }\end{array}$ \\
\hline \multirow[t]{4}{*}{2} & Protoplasts, unwashed & 11 & 81 & $\begin{array}{l}\text { Complete within } \\
\text { few minutes }\end{array}$ \\
\hline & Membranes, unwashed & 16 & 78 & $\begin{array}{l}\text { Complete within } \\
\text { few minutes }\end{array}$ \\
\hline & $\begin{array}{l}\text { Large particles obtained } \\
\text { by water-lysis of un- } \\
\text { washed membranes }\end{array}$ & $\mathbf{0}$ & 100 & Not tested \\
\hline & $\begin{array}{l}\text { Supernatant from water- } \\
\text { lysed unwashed membranes }\end{array}$ & 19 & 88 & Not tested \\
\hline \multirow[t]{4}{*}{3} & $\begin{array}{l}\text { Membranes, washed } \\
3 \text { times }\end{array}$ & $\mathbf{0}$ & 100 & None, after $24 \mathrm{hr}$. \\
\hline & Wash from membranes & 14 & 75 & Not tested \\
\hline & $\begin{array}{l}\text { Large particles from } \\
\text { membranes }\end{array}$ & $\mathbf{0}$ & 100 & None, after $24 \mathrm{hr}$. \\
\hline & $\begin{array}{l}\text { Supernatant from water- } \\
\text { lysed membranes }\end{array}$ & 0 & 100 & None, after $24 \mathrm{hr}$. \\
\hline
\end{tabular}

* The percentage unneutralizable penicillinase activity was calculated by subtracting the neutralizable activity, corrected for the residual activity of the antibody-enzyme complex, from the total.

\section{Attempts to obtain soluble $\gamma$-penicillinase}

By disruption of cellular integrity (by autolysis or crushing in the Hughes' press) Pollock (1956) obtained a portion of the $\gamma$-penicillinase (c. 25-50\%) of Bacillus cereus 569 in a soluble state (i.e. non-sedimentable at 105,000 g). In the present study about $5 \%$ of $\gamma$-penicillinase produced by lysing 
protoplasts was soluble. However, by treatment of isolated cell membranes of B. cereus $569 / \mathbf{H}$ with sonic vibrations it was possible to obtain all of the $\gamma$-penicillinase in a soluble form (Fig. 3). It was found that when washed membrane particles were subjected to sonic vibrations in the presence of $0.1 \%$ gelatin at $2^{\circ}$, about $30 \%$ of the total penicillinase activity of the preparation was lost after $1 \mathrm{hr}$. However, of the activity remaining, a portion was detectable in the supernatant fluid obtained after centrifugation at $105,000 \mathrm{~g}$ within $5 \mathrm{~min}$. after treatment was begun, and after $30 \mathrm{~min}$. almost all the activity was recovered in this supernatant fluid. The insensitivity of both membrane and soluble enzyme activity to anti- $\alpha$-penicillinase serum, and the sensitivity to iodine, indicated that both the particulate and soluble enzyme

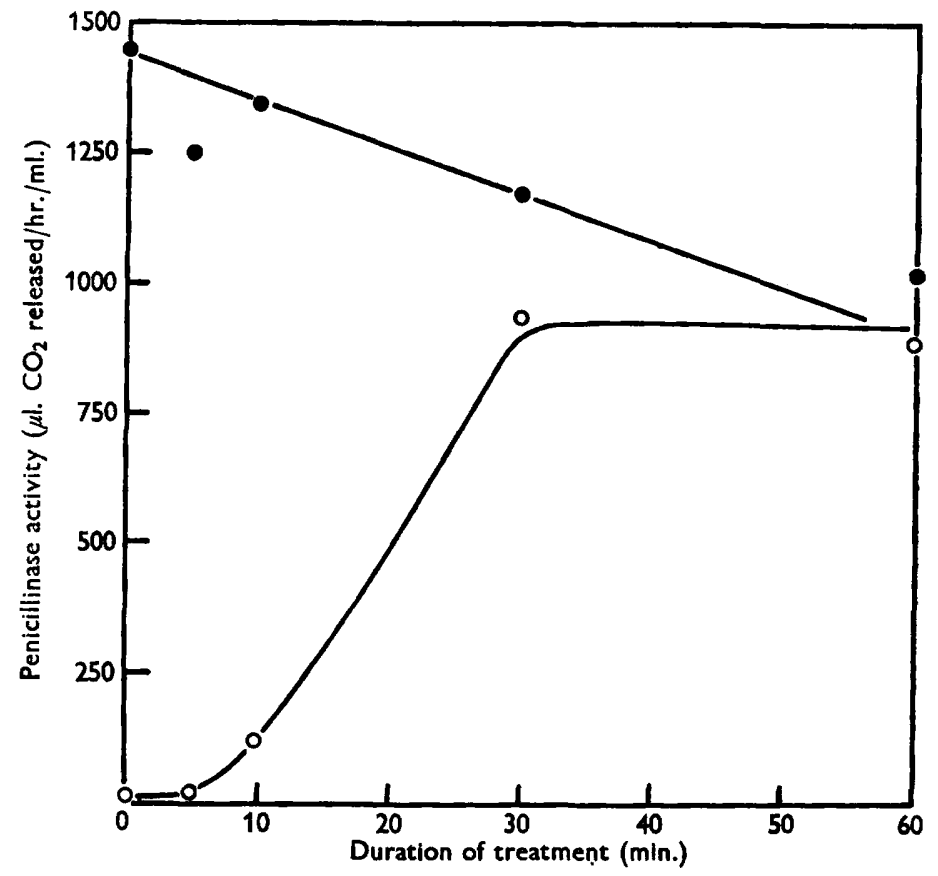

Fig. 3. Release of $\gamma$-penicillinase from washed membranes of Bacillus cereus $569 / \mathbf{H}$ in a soluble form, by treatment with sonic vibrations. A membrane preparation in $0.1 \%$ gelatin (initial volume $11 \mathrm{ml}$ ), was treated with sonic vibrations (using a $25 \mathrm{ke}$. oscillator) at $2^{\circ}$. At the noted times $2 \mathrm{ml}$. portions were removed and chilled. To each sample $12 \mathrm{ml}$. of $0.2 \%$ gelatin was added. The penicillinase activity of $1 \mathrm{ml}$. portions was measured and the remaining $13 \mathrm{ml}$. was centrifuged at $2^{\circ}$ for $1 \mathrm{hr}$. at 105,000 $\mathrm{g}$. The enzyme activity of the supernatant and the pellet (resuspended in $0.2 \%$ gelatin) was determined. $\longrightarrow$, activity of whole preparation; $\mathrm{O}-\mathrm{O}$, activity of supernatants.

under study was $\gamma$-penicillinase. It is clear that the cell-bound $\gamma$-penicillinase was removed from the membrane as soluble $\gamma$-penicillinase, by sonic vibrations. Studies with butanol and toluene indicated that these fat solvents were also active in releasing $\gamma$-penicillinase from the membrane in a soluble and active state. 


\section{DISCUSSION}

The demonstration by Weibull (1953) that treatment of Bacillus megaterium KM in hypertonic medium with lysozyme resulted in the degradation of the cell wall and the release of protoplasts marked a new phase in the study of cell physiology and biochemistry. Such controlled morphological dissection of bacteria made feasible an extension of the investigation of the structural basis of cellular activity, previously carried out by the techniques of light and electron microscopy, histochemistry, differential centrifugation of cellular components, etc. (see Sjöstrand, 1957; Gomori, 1957; Hogeboom, 1955). In particular it became possible to isolate the cell membrane and to analyse directly its chemical, biochemical and physiological properties. The chemical evidence accumulated to date (Weibull, 1957; Mitchell \& Moyle, 1956a, $b$; Gilby, Few \& McQuillen, 1958; Gilby \& Few, 1958) indicates that, for three different species of bacterium, the cytoplasmic membrane is lipoprotein in nature and contains small amounts of carbohydrate material.

Of very great interest is the finding that the cell membrane exhibits a large number of enzyme activities. Weibull (1953) and Mitchell \& Moyle $(1956 a)$ showed that the cytochrome system of Bacillus megaterium and Staphylococcus aureus, respectively, are localized in the protoplast membrane, or particles derived therefrom. The latter authors showed that the major portion of the acid phosphatase and the succinic and lactic acid dehydrogenases of $S$. aureus are to be found in particles thought to come from the cell membrane. Storck \& Wachsman $(1957 a, b)$ located all of the succinic, lactic and $\alpha$-ketoglutaric dehydrogenase activities and half of the malic dehydrogenase activity in the cytoplasmic membrane of $B$. megaterium.

In the present study it has been found that essentially all of the cell-bound penicillinase of Bacillus cereus 569 and $B$. cereus $569 / \mathrm{H}$ is associated with the cell membrane and cell wall. The $\beta$-penicillinase can be completely removed by extensive washing. This suggests that this fraction is loosely adsorbed at the cell surface. The $\gamma$-penicillinase on the other hand is very firmly attached to the cell membrane, and is only released in a soluble form as a result of disruption of the membrane, e.g. by mechanical disintegration or by treatment with lipid solvents. The observation that butanol and toluene are effective in dissolving the $\gamma$-penicillinase away from the membrane suggests that this enzyme may be present in the membrane in lipo-protein binding.

The detection of the various enzymes discussed above, in the cytoplasmic membrane, raises the question of the site of their synthesis. The demonstration that the penicillinase of Bacillus cereus is present in the extracellular medium, or else is to be found closely associated with the cytoplasmic membrane and cell wall, and is barely, if at all, detectable in the cytoplasm, does not exclude the possibility that these enzymes are formed within the cell and are later transported into and across the membrane. However, it seems rather more likely that the cytoplasmic membrane itself may be the site of such enzyme formation. Indeed the experiments of Spiegelman (1957), Hunter, Crathorn \& Butler (1957), Nisman, Bergmann \& Berg (1957), 
Butler, Crathorn \& Hunter (1958) and Brown \& Brown (1958) suggest that the cell membrane may be directly involved in the early stages of protein synthesis (i.e. activation of amino acids and transfer to an acceptor site), and that it may also participate in fashioning the final protein. Preliminary experiments have shown that penicillinase formation occurs in partiallylysed protoplasts of $\boldsymbol{B}$. cereus. These studies are to be extended in an effort to throw some light on these problems.

The author wishes to express her thanks to all the members of the Division of Bacterial Physiology, and in particular to Dr M. R. Pollock and Dr H. J. Rogers, for their kind hospitality, their continued help and critical discussion throughout her stay. The technical assistance of Mr N. Dickens is gratefully acknowledged. The author is a fellow of the National Cancer Institute of Canada.

\section{REFERENCES}

Brenner, S., Dark, F. A., Gerhardt, P., Jeynes, M. H., Kandler, O., Kellenberger, E., Kleinberger-Nobel, E., McQuillen, K., Rubio-Huertos, M., Salton, M. J. R., Strange, R. E., Tomcsik, J. \& Weibull, C. (1958). Bacterial protoplasts. Nature, Lond. 181, 1713.

Brown, G. L. \& Brown, A. V. (1958). Fractionation of deoxyribonucleic acids and reproduction of $T_{2}$ bacteriophage. In The Biological Replication of Macromolecules, Symposium Soc. Exp. Biol. 12, 6. Ed. F. K. Sanders. Cambridge University Press.

Butler, J. A. V., Crathorn, A. R. \& Hunter, G. D. (1958). The site of protein synthesis in Bacillus megaterium. Biochem. J. 69, 544.

Citri, N. (1958). Two antigenically different states of active penicillinase. Biochem. Biophys. Acta, 27, 277.

CLARK, W. M. (1928). The Determination of Hydrogen Ion, 3rd ed. p. 214. London: Baillière, Tindall and Cox.

Dark, F. A. \& Strange, R. E. (1957). Bacterial protoplasts from Bacillus species by the action of autolytic enzymes. Nature, Lond. 180, 759 .

Grlby, A. R. \& FEw, A. V. (1958). Lutein in a bacterial membrane. Nature, Lond. $182,55$.

Gilby, A. R., Few, A. V. \& McQuillen, K. (1958). The chemical composition of the protoplast membrane of Micrococcus lysodeikticus. Biochim. Biophys. Acta, 29, 21.

Gomori, G. (1957). Histochemical methods for enzymes. In Methods in Enzymology, vol. 4, p. 381. Ed. S. P. Colowick \& N. O. Kaplan. New York: Academic Press.

Henry, R. J. \& Housewright, R. D. (1947). Studies in penicillinase. II. Manometric method of assaying penicillinase and penicillin, kinetics of the penicillinpenicillinase reaction and the effect of inhibitors on penicillinase. J. biol. Chem. $167,559$.

HоGевоом, G. (1955). Fractionation of cell components of animal tissues. In Methods in Enzymology, vol. 1, p. 16. Ed. S. P. Colowick \& N. O. Kaplan. New York: Academic Press.

Hunter, G. D., Grathorn, A. R. \& BUtler, J. A. V. (1957). Sites of incorporation of an amino acid into proteins of Bacillus megaterium. Nature, Lond. 180, 383.

KANTOROwicz, O. (1951). Shaking apparatus for the aeration of bacterial cultures. J. gen. Microbiol. 5, 276.

Kogut, M., Pollock, M. R. \& Tridgell, E. J. (1956). Purification of penicillininduced penicillinase of Bacillus cereus NRRL 569: a comparison of its properties with those of a similarly purified penicillinase produced spontaneously by a constitutive mutant strain. Biochem. J. 62, 391. 
Kramer, M. \& Straub, F. B. (1955). Inductive synthesis of penicillinase in cell free preparations of Bacillus cereus. Acta Physiol. Hung. 7, 167.

McQuillen, K. (1958). Bacterial 'protoplasts': effects of diaminopimelic acid deprival and penicillin addition compared in Escherichia coli. Biochim. Biophys. Acta, 27, 410.

McQuillen, K. (1959). Bacterial protoplasts. In The Bacteria, vol. 1, chap. 7. Ed. I. C. Gunsalus \& R. Y. Stanier. New York: Academic Press (in the Press).

Mitchell, P. \& Moyle, J. (1956a). The cytochrome system in the plasma membrane of Staphylococcus aureus. Biochem. J. 64, 19 P.

Mitchell, P. \& Moyle, J. (1956b). Osmotic structure and function in bacteria. In Bacterial Anatomy, Symp. Soc. gen. Microbiol. 6, 150. Ed. E. T. C. Spooner $\&$ B. A. D. Stocker. Cambridge University Press.

Nisman, B., Bergmann, F. H. \& Berg, P. (1957). Observations on amino aciddependent exchange of inorganic pyrophosphate and ATP. Biochem. Biophys. Acta, 26, 639.

Pollock, M. R. (1950). Penicillinase adaptation in B. cereus: Adaptive enzyme formation in the absence of free substrate. Brit. J. exp. Path. 31, 739.

Pollock, M. R. (1953). Penicillinase adaptation and fixation of penicillin sulphur by Bacillus cereus spores. J. gen. Microbiol. 8, 186.

Pollock, M. R. (1956). The cell-bound penicillinase of Bacillus cereus. J. gen. Microbiol. 15, 154.

Pollock, M. R. (1957). A simple method for the production of high titre penicillinase. Pharm. pharmacol. 9, 609.

SuöstraNd, F. S. (1957). Electron microscopy of cellular constituents. In Methods in Enzymology, vol. 4, p. 391. Ed. S. P. Colowick and N. O. Kaplan. New York: Academic Press.

Spiegelman, S. (1957). Nucleic acids and the synthesis of proteins. In The Chemical Basis of Heredity, p. 232. Ed. W. D. McElroy and B. Glass. Baltimore: The Johns Hopkins Press.

Storck, R. L. \& Wachsman, J. T. (1957 $a)$. The association of enzymes with the protoplast membrane of Bacillus magaterium. Biochem. J. 66, 19 P.

Storck, R. L. \& Wachsman, J. T. (1957b). Enzyme localization in Bacillus megaterium. J. Bact. 73, 784.

Strange, R. E. \& Dark, F. A. $(1957 a)$. A cell-wall lytic enzyme associated with spores of Bacillus species. J. gen. Microbiol. 16, 236.

Strange, R. E. \& Dark, F. A. (1957b). Cell wall lytic enzymes at sporulation and spore germination in Bacillus species. J. gen. Microbiol. 17, 525.

WeIBULL, C. (1953). Characterization of protoplasmic constituents of Bacillus megaterium. J. Bact. 66, 696.

Weibull, C. (1956). The nature of the 'ghosts' obtained by lysozyme lysis of Bacillus megaterium. Exp. Cell Res. 10, 214.

WeIBULl. C. (1957). The lipids of a lysozyme-sensitive Bacillus species (Bacillus ' $M$ '). Acta chem. Scand. 11, 881.

\section{EXPLANATION OF PLATE}

Figs. 1, 2. Electron micrographs of preparations of Bacillus cereus 569/H. Fig. 1. Protoplasts, prepared as described under Methods. Fig. 2. Protoplast to left of spore. Magnification, c. $\times 16,000$. The electron micrographs were taken by Dr R. C. Valentine.

Fig. 3. Electron micrograph (taken by $\mathrm{Dr}$ R. C. Valentine) of a protoplast membrane of Bacillus cereus 569/H. Magnification, c. 16,000. 
Journal of General Microbiology, Vol. 21, No. 1
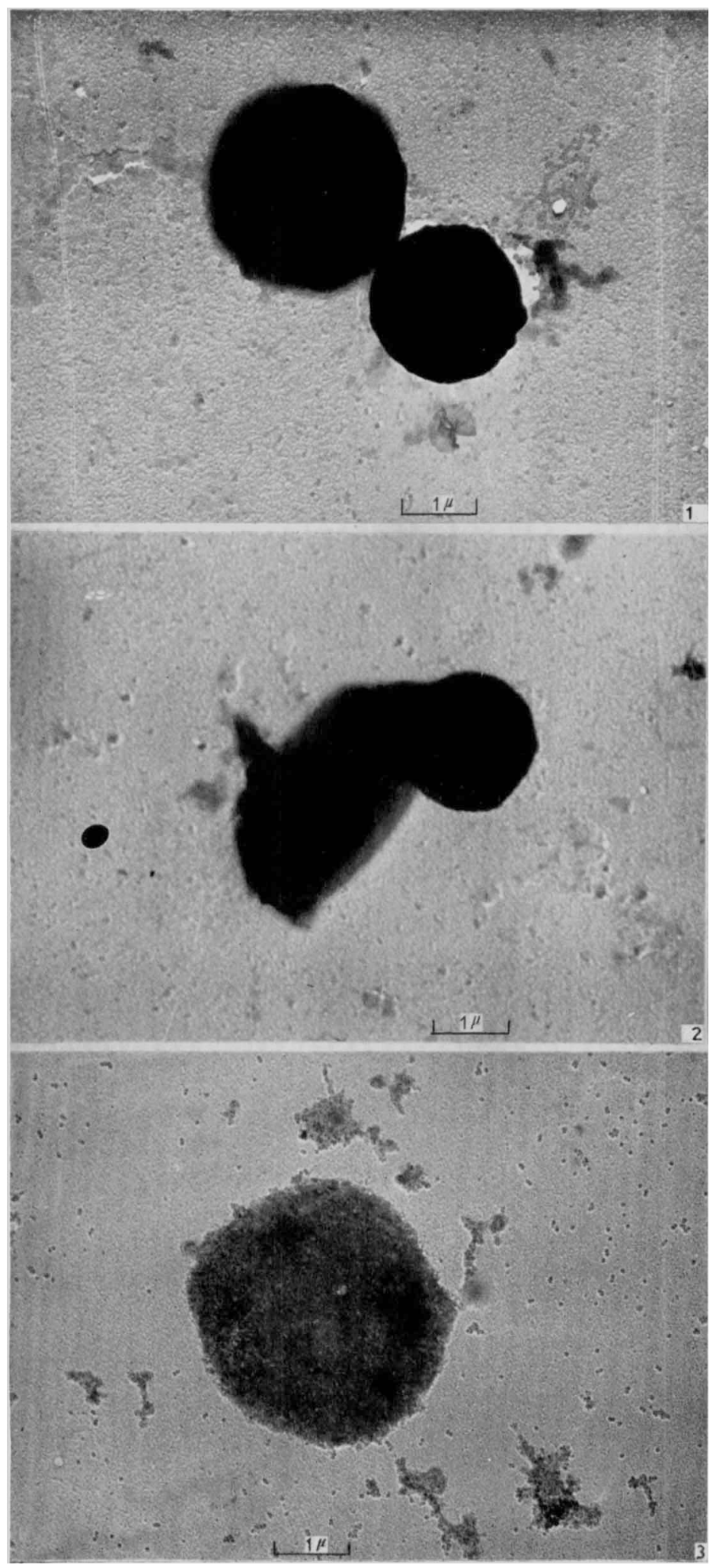

IR. Sheinin-Penicillinase in Protoplasts

(Facing p. 134) 